Foi assim

\title{
(OU, DE COMO ESCREVI MEU ÚLTIMO LIVRO)
}

Em Nosotros, seu mais recente livro, publicado ano passado pela Editora Brasiliense, Renata Pallottini constrói, com poesia, um relato de sua viagem a Cuba. No artigo a seguir ela conta, com exclusividade para a revista Comunicação e Educação, como esse livro foi elaborado.

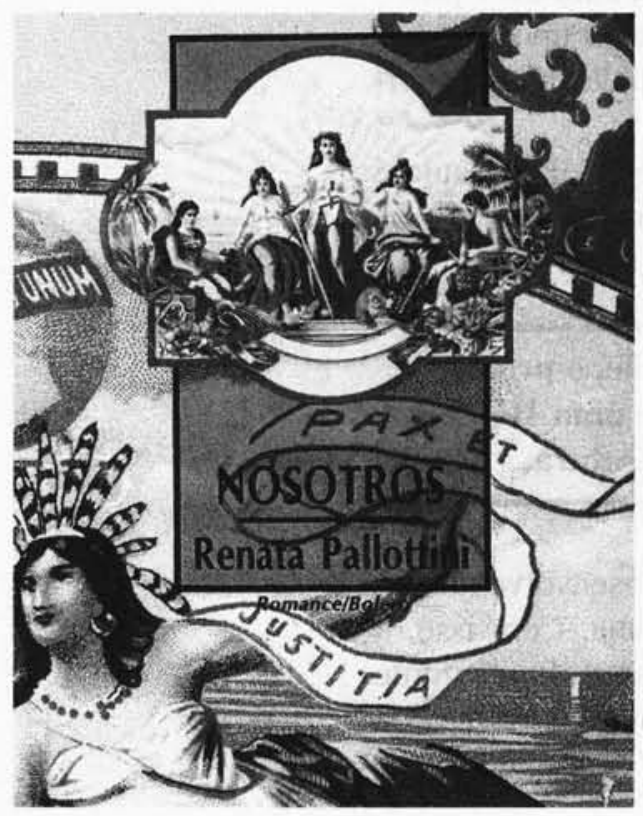

A AUTORA

Renata Pallottini

Professora Doutora e Chefe do Departamento de Artes Cênicas da ECA-USP, autora de poesia, teatro e prosa. Seu último livro, Nosotros, foi editado pela Brasiliense (São Paulo, 1994).
Sempre me pareceu que as viagens davam boa matéria de memória (esta expressão pertence a alguém, mas não sei mais quem); que propiciavam a escrita, sob qualquer forma literária. Claro está que a primeira forma que ocorreria ao escritor seria o relato de viagem, a crônica do peregrino que conta suas peripécias, ao mesmo tempo que ilustra a narrativa com postais (às vezes em sentido figurado, às vezes não) dos lugares percorridos. Mas isso nunca me pareceu satisfatório.

Achava eu que a crônica de viagem dava sempre a impressão de coisa truncada: faltava a visão concreta por parte do leitor, a sua própria experiência.

Em suma: para mim, a não ser em casos muito raros, a narrativa de viajantes modernos se assemelhava aos folhetos de agência de turismo.

Por isso, quando decidi pôr em ordem as minhas anotações, invenções, observações e, mais, os recortes de jornal 
que havia acumulado em seis anos de visitas a Cuba, visitas que tinham totalizado ano e meio de vida por lá, fiquei em dúvida. Que fazer com tudo aquilo? Crônica de viagem, nem pensar. Poesia, claro, sempre, mas aquilo era outra coisa, menos subjetiva, mais concreta e referente a fatos.

Custou-me convencer-me de que poderia escrever um romance; $\mathrm{o}$ gênero me parecia interdito à minha experiência até aqui,

feita ou de forma fragmentada, desejadamente fragmentada, como ocorre na Poesia, ou basicamente dialogada, como ocorre no Teatro. As demais coisas que tinha feito eram acidentais: histórias infantis, roteiros de televisão, contos, ensaios. Isso pensava eu.

Refletindo melhor percebi que, na verdade, o que estava fazendo ao longo da vida era, simplesmente, escrever. Escrever escolhendo o gênero de acordo com as necessidades da escrita; ou melhor, deixando que a escrita escolhesse o seu próprio gênero. $\mathrm{E}$ isso ia muito ao encontro do meu maior objetivo: o da Liberdade.

Se penso a liberdade antes de pensar qualquer coisa, por que não poderia pensar a liberdade no ato de escrever e de escolher o gênero de escrita?

E, aliás, não é essa uma inquietação do escritor atual? Sabemos nós $o$ que é o que, na efervescência da produção?

Aí, naturalmente, colocava-se o problema de vencer o espaço que há entre o que se é e o que se quer ser; ou seja, em palavras mais simples: seria eu capaz de escrever um romance, ainda que fosse um romance sui generis, ainda que fosse um romance-bolero?

Não havia maneira de saber senão fazendo.

Foi assim: comecei a juntar (e nesse ato já comecei a pôr o carinho que permearia a obra) o material que tinha coletado naqueles seis anos; ali havia tudo: histórias, depoimentos, fotos, recortes de jornal, apontamentos de ficção, esboços de personagens. Conquanto tudo se passasse num mesmo espaço e num mesmo tempo, principalmente sob as mesmas condições sociais e existenciais, naturalmente não havia um fio condutor da história, e não havia, mais grave ainda, o que unisse ficção e realidade. Eu compreendia que, às vezes, o relato real semelharia uma história inventada, e vice-versa. 
Quando se olha com atenção e uma espécie de amor interessado para os relatos das agências noticiosas que provêm de certas partes do mundo, o fato parece história fantástica.

Como diz Alejo Carpentier, "na América Latina, o épico é coisa cotidiana". Daí o "real maravilhoso", característica do prosador cubano.

Por qualquer razão misteriosa escondida no subconsciente, minha história se baseava em motoristas, em condutores de qualquer tipo de automóvel. Creio que aí entrava muito essa forma de dificuldade crescente que os choferes enfrentam em Cuba; é preciso que uma pessoa seja hábil, valente, criativa para guiar qualquer veículo automotor, na Havana dos nossos dias. E foi aí e assim que a narrativa começou.

Em primeiro lugar, nasceu o chofer de ônibus cubano, o guagüero (ou seja, condutor de guagua, ônibus, em cubano) Pedro Miguel; depois, o motorista de carro da Embaixada, o brasileiro Waldomiro; e, por fim, Epifânio, o negro que guia táxi de turismo ou o que tiver que guiar.

A partir daí, a história começou a montar-se; era uma narrativa em que todos, personagens habaneros, personagens campesinos, personagens brasileiros, e narrador, formávamos um grupo, um conluio, ninguém diante de ninguém, mas todos juntos: nosotros, nós, aliados, companheiros.

Mas aqui entrava outra dificuldade: a questão do ponto de vista. Quem, dentre os personagens, narrava? Quem, de fora, objetivo, via?

A opção foi novamente a de multiplicar os narradores. Além de personagens-narradores (vários, dentre os protagonistas, e especialmente Miro, Pedro Miguel, Epifânio), há o ponto-de-vista do próprio narrador-autor, expresso em trechos seus, objetivos, de fora e, mais, trechos e recortes de jornais, cartas, poemas e, até, a intercalação de um trecho de peça de teatro, da própria autora original.

Neste caso, o do teatro inserido na prosa ficcional, o que ocorreu foi uma descoberta que a mim própria surpreendeu.

Percebi, ao reler, vinte e tantos anos depois, $O$ Escorpião de Numancia, recriação do texto original de Cervantes, que minha peça, uma alegoria que aproximava o cerco de Cuba ao do burgo numantino, estava perfeitamente atual. 
Em O Escorpião de Numancia, a certa altura da peça, os numantinos, submetidos a um cerco que dura anos, têm de escolher entre render-se ou deixar-se morrer de fome. A história da peça é a história desse conflito. Meu texto dramático foi escrito em 1967, publicado e encenado entre 1968/69. E tem tudo a ver com Nosotros!

Do conteúdo não há muito mais a dizer; seria desejável que se lesse o livro... Aliás, talvez seja também didático prosseguir descrevendo os passos que o escritor efetiva, no seu caminho para a edição de um trabalho. Muitos autores - que não tenham tido, é claro, sua produção já encomendada anteriormente pelo editor - enviam cópias do original para várias casas editoras ao mesmo tempo e depois esperam o resultado das várias tentativas. Nunca consegui fazer isso; $\mathrm{e}$, às vezes, até me dei mal. Mas sigo no mesmo comportamento.

Neste caso, mandei os originais para a Editora Brasiliense, valendo-me de um velho encontro cordial que havia tido com Danda Prado; pouco tempo depois ela me telefonou dizendo que queria publicar o livro. O caminho, neste caso, foi suave e tem prosseguido assim.

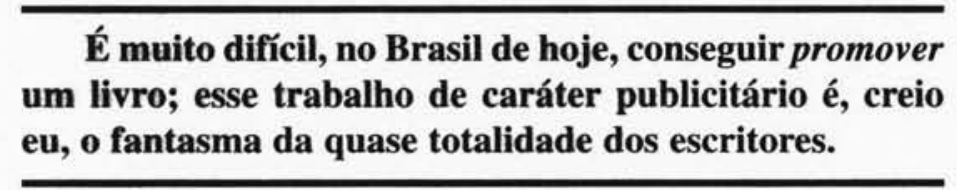

Alguns se recusam de vez a aparecer, falar sobre, vender o seu livro. E têm, em tese, razão. A mim me dá muita pena ver que um livro onde tentei pôr meu possível talento, meu indiscutível trabalho e, principalmente, minhas esperanças de ajudar a discutir um grave problema - o da sobrevivência cubana - fique escondido. Por isso, já que todos cantam sua terra, também vou cantar a minha! $\mathrm{E}$ a tua e a deles e a de nosotros. 